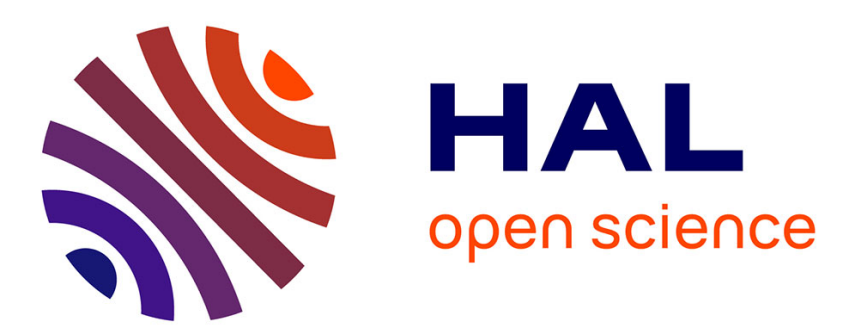

\title{
Computers and Welfare: The Swedish Debate on the Politics of Computerization in the 1970s and the 1980s Per Lundin
}

\section{To cite this version:}

Per Lundin. Computers and Welfare: The Swedish Debate on the Politics of Computerization in the 1970s and the 1980s. 4th History of Nordic Computing (HiNC4), Aug 2014, Copenhagen, Denmark. pp.3-11, 10.1007/978-3-319-17145-6_1 . hal-01301200

\section{HAL Id: hal-01301200 \\ https://hal.inria.fr/hal-01301200}

Submitted on 11 Apr 2016

HAL is a multi-disciplinary open access archive for the deposit and dissemination of scientific research documents, whether they are published or not. The documents may come from teaching and research institutions in France or abroad, or from public or private research centers.
L'archive ouverte pluridisciplinaire HAL, est destinée au dépôt et à la diffusion de documents scientifiques de niveau recherche, publiés ou non, émanant des établissements d'enseignement et de recherche français ou étrangers, des laboratoires publics ou privés. 


\title{
Computers and Welfare: The Swedish Debate on the Politics of Computerization in the 1970s and the 1980s
}

\author{
Per Lundin \\ Dept. of Technology Managements and Economics, Chalmers University of Technology, \\ SE-412 96 Gothenburg, Sweden \\ per.lundin@chalmers.se
}

\begin{abstract}
In the 1950s and 1960s computers became part and parcel of the great modernization project - the creation of the modern welfare state. The ability to control and rationalize provided by the digital technology proved indispensable for the expanding public sector as well as for trade and business. At the turn of the decade, the effects of the new technology on Swedish society became increasingly apparent. This paper examines the debate on computer and politics in Sweden during the 1970s and the 1980s. It particularly discusses two issues that were hotly debated: integrity and jobs. The debate was occupied with the centralized solutions and systemic effects large-scale computing implied. In this debate computing technology was perceived as a threat, but at the same time there was a widely shared belief amongst debaters that it was possible to take control of the technology.
\end{abstract}

Keywords: computing policy, history of computing, integrity, IT-history, Sweden, unemployment, welfare

\section{Introduction}

In this paper I give an overview of the debate on computer and politics in Sweden during the 1970 s and 1980 s. During this period, civil society organizations, especially the large social movements, and political parties elaborated manifestos and programmes that presented explicit computing policies. Writers and journalists discussed the pros and cons of the digital technology and its impact on society. Government commissions, government bodies and later also researchers investigated the social consequences of the computing technology and suggested possible measures. In the early 1990s, the interest in debating computers and politics dwindled, and in 1995 a commentator promptly declared that 'datapolitik', e.g. computing politics, was an extinct subject [1].

Admittedly, the politics of computerization has been considered in the earlier literature. However, the focus has been more on (the lack of) government policies for research and development, and less on the broader public discourse on computer and politics [2-4]. The most detailed account up-to-date is still the political scientist Kent 
Lindkvist's research paper Datateknik och politik [Computing Technology and Politics] (1984) [5].

In the 1950s and 1960s computers became part and parcel of the great modernization project - the creation of the modern welfare state. While computers in the 1950s and the early 1960s had been used mainly for techno-scientific computing, often for military purposes, by the end of the 1960s they became increasingly used, and associated with, the gathering and processing of data for bureaucratic or commercial purposes. Indicative of this change is the location of computing expertise in the government apparatus. The Swedish Board for Computing Machinery (Matematikmaskinnämnden, MMN), which had been established in 1948, hosted initially the government's computing expertise. MMN belonged to the Ministry for Education until 1961 when it was moved to the Ministry for Finance. Two years later, in 1963, MMN was discontinued, and the Swedish Agency for Public Management (Statskontoret) at the Ministry for Finance took over the overarching responsibility. Hence, the minister of finance became de facto minister of computing. The ability to control and rationalize provided by the digital technology proved indispensable for the expanding public sector as well as for trade and business. At the turn of the decade, the effects of the new technology on Swedish society became increasingly apparent [6-9].

The period 1968-70 marks the beginning of the public debate on computing and politics as well as the end of the privileged and unchallenged position that computing expertise had enjoyed during the previous decades. As the historian Lars Ilshammar shows, the number of computer-related initiatives in the Swedish Parliament skyrocketed during this period [10]. An important event was the publication of Datorer och politik [Computers and Politics] (1970) by the political scientist Jan Annerstedt and his co-authors (Lars Forssberg, Sten Henriksson and Kenneth Nilsson). They argued that the use of digital technology had served to manifest and consolidate the existing power structures in society. They exposed the close connections between the state apparatus and trade and business, especially the multinational IBM. In the book's concluding section Annerstedt pointed out that despite the far-reaching political consequences of the new technology the Swedish government lacked an explicit computing politics. Although the book presented an almost conspiratorial plot, in a manner typical of this radical period in history, it nevertheless identified many of the key problems with the narrow societal control of the new technology [3]. Admittedly, Datorer och politik was not the first book that stressed the dangers of an unfettered use of digital technology. Earlier notable books such as the Swedish physicist Hannes Alfvén's Sagan om den stora datamaskinen [The Tale of the Big Computer] (1966) and the Danish computing scientist Peter Naur's Datorerna och samhället [Computers and Society] (1969) might be mentioned - but Annerstedt's book was arguably the publication that received most attention [11, 12].

Especially two issues became hotly debated during the following couple of decades: integrity and jobs. Below I investigate them in more detail. Kent Lindkvist claims that a third issue also caught the public's attention, namely vulnerability [5]. In this paper, however, I will not further discuss this issue. My choice is motivated by the fact that the debate on vulnerability was more limited in scale and scope. In my analysis, I focus particularly on the role of political parties, trade unions and other civil society organizations, debaters, and the media. Hence, I will not closer examine the role of the many government commissions launched during the 1970s and the 
1980s or the large government-sponsored research programmes starting above all in the 1980 s.

\section{Debating Integrity}

Part of the post-war welfare state project had been the development and use of large databases and registers dealing with personal data, and at the onset of the 1970s the issue of integrity came into the fore. The 1970 Population and Housing Census conducted by the National Central Bureau of Statistics (Statistiska centralbyrån, SCB) sparked a heated debate. During the autumn 1970, debaters and the media targeted SCB. Leftists accused SCB of selling the data gathered for commercial purposes. Liberals and Conservatives dominated the debate, however. If left-wing debaters were concerned about the commercialization of personal data, Liberal and Conservative voices worried about the privacy of the individual citizen and feared the coming of a socialist 'Big Brother' society. The question of integrity soon entered the Swedish Parliament. Especially the Swedish Left Party (Vänsterpartiet kommunisterna, VPK), the Liberal Party (Folkpartiet, FP), and the Centre Party (Centerpartiet, C), the former Agrarian Party, were active. Admittedly, the issue of computing technology and integrity was already under investigation by a governmental commission, but the debate on SCB's census undoubtedly catalysed its work, and in 1972 the commission presented its official report Data och integritet (Data and Integrity). The commission's work led to the Data Act of 1973, which presented a far-reaching legislation concerning data registers and credit reports $[5,10,13]$.

The debate and the legislation spurred political parties from the left to the right as well as civil society organizations to discuss the politics of computerization, and during the 1970s computing politics became an established concept [1,5].

Liberals and Conservatives voiced above all concerns for personal integrity. The Conservative Party (Moderata samlingspartiet, M), for example, feared that an omnipotent state would use the computing technology, and in particular the data registers, for developing a more effective control of its citizens. The Left, on the other hand, expressed concerns over integrity at the work place. For instance, the Swedish Left Party viewed the integrity issue from a class perspective. The party did not oppose data registers per se, but it wanted them to be adapted to the employees' interests, not the employers'. Until the general election in 1976, the Social Democratic Party (Socialdemokratiska arbetarepartiet, SAP) was the political party in power. By contrast, it tended to view the question of integrity as a non-political, technical issue, and the party also painted a much brighter image of the role of digital technology for the individual citizens. In the late 1970s, after having gone into opposition, SAP developed a more explicit computing politics. Integrity was not a prominent feature of its politics, however. The party, which was intimately associated with post-war reforms in both welfare and warfare, preferred to link integrity to the question of national security, i.e. the integrity of the nation against other nations [5, $14,15]$.

The single most influential voice in the debate was the Liberal Member of Parliament, Kerstin Anér. In her book Datamakt [Computer Power] (1975) she exposed the ambitions of the state as well as the corporations to control, and she empathically defended the right and the need for individuality [16, 17]. As my 
examples have illustrated, the worries that the freedom and privacy of the citizens would be restricted came above all from the political right. Consequently, civil society organizations loosely connected to the Liberals or the Conservatives took a similar stance. Examples include the Free Churches and the temperance movement. Often the argument centred on the privacy of the family and in particular small children. Among the individual debaters that presented arguments in this vein the journalist Margareta Calmgård Bergmark might be used as an illustration. In her book Människan i datorsamhället [Man in the Society of Computers] (1981), she presented herself as a mother of small children, who worried over the encroaching of computers upon private life. Calmgård Bergmark raised the question if the gains in efficiency really would counter the loss of privacy [18].

Although the debate on integrity was most intensive during the 1970s, it continued well into the 1980s. Lars Ilshammar highlights two controversial projects: the debates around FOBALT in 1983 and the Metropolit project in 1986. FOBALT was a planned alternative population and housing census, that in order to reduce the administrative costs would link and match about twenty registers from different government authorities. The criticism was vehement. Metropolit, in turn, was a research project in sociology at Stockholm University that had collected personal data for approx. 15,000 inhabitants in Stockholm during a period of twenty years. The inhabitants, all born in 1953, had neither been consulted nor informed. When the largest Swedish daily, Dagens Nyheter, in February 1986 exposed the scale and scope of the project, it led to a storm of protests, and later the same year the project was ended. Ilshammar argues that the Metropolit controversy marked an end of the debate on integrity. During the second half of the 1980s, computers were less and less perceived as a threat against personal integrity, and the negative connotations of computerization were gradually replaced with positive ones. When the Liberal Party as part of the non-Socialist government during the period from 1991 to 1994 suggested that the personal numbers should be abolished, the political interest was lukewarm at the most. Integrity had ceased to be a political conflict zone [10].

\section{Debating Jobs}

If the debate on integrity was led by Liberals and Conservatives, as well as civil society organizations such as the Free Churches and the temperance movement, the debate on the effects of the computer-based rationalization and its ultimate consequence, unemployment, was above all sustained by the political left and the labour unions.

The early 1970s marked the end of the phenomenal growth that had characterised the preceding decades. By the mid-70s, if not earlier, it had become painstakingly apparent that the computer was a powerful rationalization tool, and that the wave of computer-led rationalization had begun to hit new groups such as blue-collar workers. Previously white-collar workers had been affected by the rationalization, but because of the booming economy of the 1950s and the 1960s, the result had almost never been unemployment since new jobs had been created. In the 1970s, however, the computerbased wave of rationalization coincided with the economic recession, and many occupational groups feared they would lose control over their work and eventually 
their jobs. It was particularly with the 'microelectronics revolution', which took off in the mid-1970s, that computers began to transform working life [19, 20].

The labour movement reacted swiftly, however. Interestingly, the governing Social Democrats and the trade unions regarded technology and technological change as a prerequisite for realizing material and social welfare. The technological optimism of the labour movement was manifested at the so-called Rigoletto Conference, organised by the Social Democrats in 1955. It featured a broad assembly of scientists and technicians, politicians and trade union leaders, and representatives for trade and industry. The resulting publication Tekniken och morgondagens samhälle [Technology and the Society of Tomorrow] (1956) communicated a solid belief in technology and science. The trade unions shared this approach. The Trade Union Confederation (Landsorganisationen i Sverige, LO), for instance, adopted a 'rationalization friendly approach', i.e., a strategy of adaptation towards technological change [21, 22].

At the onset of the 1970s, a very strong labour movement expanded its ambitions from wage negotiations into changing work organization and eventually also technology. An example of this active and technology-friendly strategy was the Trade Unions Confederation's decision to present an action programme labelled Företagsdemokrati och data [Industrial Democracy and Data] (1975), and the subsequent decision in 1976 to launch the Trade Unions Confederation's Advisory Committee for Computing (LO's dataråd). The programme and the committee stated that the trade unions moved from 'defensive' to 'offensive' strategy. Rather than being the passive object of automation, the worker should be an active subject in shaping technological change. Thus, it would be possible to counter the degradation of work that many believed would be the result of an uncontrolled use of digital technology in working life [23-25]. The Swedish Confederation of Professional Employees (Tjänstemännens centralorganisation, TCO) took a similar stance. The organization put a particular emphasis on the issue of integrity at work. In its programme for computing politics, Datorerna och arbetslivet [Computers and Working Life] (1978), it maintained that computer-based methods-time measurement (MTM) systems controlled the employees to a too high extent and threatened the personal integrity. It was crucial, the Swedish Confederation of Professional Employees argued, that employees were given the possibility to participate in the development of the computer systems [26]. Eventually, the Social Democratic Party would follow suit, and in 1978 the party presented an action programme on computers and politics, Datorer på människans villkor [Computers on the Conditions of Man]. In the programme it was observed that computers had become an integral part of society, and it was argued that 'computerization' was a central political issue [14].

Tage Erlander's Computer Symposium in 1980 became an important political manifestation of this posture. Named after a former social democratic prime minister, the symposium can be described as a summit conference for the labour movement. Social democratic top politicians as well as trade union leaders participated. The message conveyed at the conference and in the subsequent publication Datorerna och samhällsutvecklingen [Computers and the Development of Society] was that computing technology was beneficial if it was possible to control it politically [27]. 


\section{Computers and Control}

As we have seen, different social groups promoted and debated the issues of integrity and jobs, respectively. More often than not did they represent radically different social values and political ideologies. Nevertheless, their responses toward the new digital technology displayed several common features.

The debates I have surveyed were by and large occupied with the use and effects of mainframe computers. They did not deal with mini computers or, more importantly, personal computers and the new patterns in use emerging with them. Rather they were occupied with the centralized solutions and systemic effects that large-scale computing implied. Thus, issues of control appeared at the core of the debates. The computing technology was perceived as a threat towards personal integrity or work. But at the same time there was a widely shared belief amongst debaters that it was possible to take control of the technology. As the above-mentioned Kerstin Anér stressed it was nonsensical to break the computing machinery into pieces like the Luddites once had done. However, she continued, it was necessary to develop a legislation to control the computing technology. Furthermore, it was necessary to choose between the different possibilities available [16]. That a Liberal Member of Parliament should argue against Luddism was not so surprising, however. After all, Luddism was a desperate reaction from workers losing control over their work. But Swedish workers and their organizations did not express much sympathy for machine breaking either. As I have discussed elsewhere, technological optimism was a distinct feature of the Nordic labour movements, which separated them from the Anglo-Saxon labour movements who often viewed technological change with suspicion [19]. As we have seen above, the Swedish labour movement maintained that by controlling technology it would be possible to develop it on the premises of the workers. Thus, debaters on both the right and the left drew the conclusion that it was possible to control and even to choose digital technology, and that it ultimately was a matter of politics. It was not technology, but politics that dictated our future.

Another common feature of the debaters was an ambition to enlighten the general public. A characteristic trait for Sweden, and indeed the Nordic countries, is a particular educational ideal called folkbildning. It can be described as a liberal nonformal and voluntary educational system for adults, upheld by folk high schools and study associations. It was a system shaped by the large social movements such as the labour movement, the temperance movement, and the Free Churches [28, 29]. This educational ideal was important for disseminating knowledge of digital technology and for sustaining a critical discussion of its effects [30]. The Workers' Educational Association, for instance, produced course material such as Vi väljer vår framtid: Datorerna, makten och våra jobb [We Are Choosing Our Future: Computers, Power, and Our Jobs] (1983), which were used in study circles on the role of computers in social change [31-33]. Kerstin Anér collaborated with Christian organizations in the development of Styra eller styras? [Control or Be Controlled?] (1983), which served as educational material for both the Church and the Free Churches [34]. As yet another example serves the booklet Den elektroniska demokratin [The Electronic Democracy] (1984) published by the Temperance Movement's Educational Division (Nykterhetsrörelsens bildningsverksamhet) and intended for the temperance movement's study circles [35]. Many of these publications repeated observations, analyses, conclusions and reflections made in earlier programmes or manifestos. The 
publications and the study circles produced and organised under the auspices of the different civil society organizations, hence contributed to the dissemination of an awareness of the consequences of the digital technology and the importance of its politics.

\section{From Welfare to Growth}

If 1970 serves as the symbolic starting point for the debate on the politics of computerization in Sweden, the year of 1994 stands out as its symbolic ending point. A seminal event was a speech held by the Conservative Swedish Prime Minister Carl Bildt at the Royal Swedish Engineering Academy (Kungl. Ingenjörsvetenskapsakademien, IVA) on February 4, 1994. The speech with the telling title 'Sverige mot IT-toppen', e.g. 'Sweden towards the IT Top', signalled a radical shift in rhetoric. Together with the famous email exchange between Carl Bildt and US President Bill Clinton that very same month, the speech demonstrated that the concept 'IT', or 'information technology', had largely replaced 'data' as a symbol of growth and progress [10, 36, 37].

In fact, 'data' and 'IT' evoked radically different associations in the contemporary discourse. While data during the previous decades had become related to mainframe computing and large centralized systems, control and rationalization, IT was linked with personal computers and decentralized networks, communication and growth. While data stood for the closed (national) world of the Cold War order, IT represented the open (global) world of a new liberal-capitalist order. Furthermore, this conceptual shift coincided with a political shift from the collectivism of the strong state and the social democratic welfare regime to the individualism of the libertarian 'minimal state' and the neoliberal market empire. In the 1990s, a more growth-oriented IT politics would also replace the welfare-oriented computing politics of the previous decades.

\section{Integrity and Jobs Revisited}

Lately, the issues of integrity and jobs have resurfaced in the public discourse. In the wake of the Snowden affair in 2013, the rapid development and extensive use of digital surveillance technologies has once again put the issue of integrity in the limelight. And the widely noticed publication of The Second Machine Age: Work, Progress, and Prosperity in a Time of Brilliant Technologies (2014) by Erik Brynjolfsson and Andrew McAfee has led to a debate on the automation of intellectual work and the future of jobs [38]. It might be instructive to compare today's debate with the one I have surveyed in this paper. If it is at all possible to discern a politics of digital technologies today, it is an implicit one. It is definitely one that is very far from the explicit manifestos and programmes of the 1970s and 1980s. Current policies seem to adapt to a technological future that appears inevitable rather than believing that this future is possible to choose; they are reactive, not active. In hindsight, it seems as if the 1970s and 1980s harboured a belief in politics that have since been lost. 
Acknowledgements. Ridderstads stiftelse för historisk grafisk forskning has provided financial support for the research carried out in connection with this paper. Gustav Sjöblom has given valuable comments on earlier versions of this manuscript.

\section{References}

1. Henriksson, S.: Datapolitikens död och återkomst. In: Atlestam, B. (ed.): Infrastruktur för informationssamhället: Teknik och politik. Nutek, Stockholm (1995)

2. Annerstedt, J.: Staten och datorerna: En studie av den officiella datorutvecklings- och datorforskningspolitiken. Kommittén för forskningsorganisation och forskningsekonomi (FEK), Stockholm (1969)

3. Annerstedt, J., Forssberg, L., Henriksson, S., Nilsson, K.: Datorer och politik: Studier i en ny tekniks politiska effekter på det svenska samhället. Zenit, Lund (1970)

4. Glimell, H.: Återerövra datapolitiken! En rapport om staten och informationsteknologin under fyra decennier. Tema, Linköping (1989)

5. Lindqvist, K.: Datateknik och politik: Datapolitiken i Sverige 1945-1982. Forskningspolitiska institutet, Lund (1984)

6. De Geer, H.: På väg till datasamhället: Datatekniken i politiken 1946-1963. Tekniska högskolan, Stockholm (1992)

7. Dussauge, I., Gribbe, J., Kaijser, A., Lundin, P., Peralta, J., Sjöblom, G., Thodenius, B. Precursors of the IT Nation: Computer Use and Control in Swedish Society, 1955-1985. In: Impagliazzo, J., Lundin, P., Wangler, B.: History of Nordic Computing 3: Third IFIP WG9.7 Conference, HiNC 3, Stockholm, Sweden, October 18-20, 2010: Revised Selected Papers. Springer, Heidelberg (2011)

8. Lundin, P.: Computers in Swedish Society: Documenting Early Use and Trends. Springer, Heidelberg (2012)

9. Nybom, T.: Det nya statskontorets framväxt 1960-1965. In: Granholm, A., Rydén, M. (eds): Statskontoret 1680-1980: En jubileums- och årsskrift. Statskontoret, Stockholm (1980)

10. Ilshammar, L.: Offentlighetens nya rum: Teknik och politik i Sverige 1969-1999. Örebro universitetsbibliotek, Örebro (2002)

11. Alfvén, H.: Sagan om den stora datamaskinen: En vision. Bonnier, Stockholm (1966)

12. Naur, P.: Datamaskinerna och samhället: Med ett tillägg om svenska förhållanden av Sten Henriksson. Studentlitteratur, Lund (1969)

13. Söderlind, Å.: Personlig integritet som informationspolitik: Debatt och diskussion i samband med tillkomsten av Datalag (1973:289). Valfrid, Borås (2009)

14. Datorer på människans villkor: Program för datapolitiken. Sveriges socialdemokratiska arbetareparti, Stockholm (1979)

15. Lundin, P., Stenlås, N.: Technology, State Initiative and National Myths in Cold War Sweden: An Introduction. In: Lundin, P., Stenlås, N., Gribbe, J. (eds): Science for Welfare and Warfare: Technology and State Initiative in Cold War Sweden. Science History Publications, Sagamore Beach (2010)

16. Anér, K.: Den tillverkningsbara människan. Folk \& samhälle, Stockholm (1972)

17. Anér, K.: Datamakt. Gummessons, Stockholm (1975)

18. Calmgård Bergmark, M.: Människan i datorsamhället. Larson, Täby (1981)

19. Lundin, P.: Designing Democracy: The UTOPIA-Project and the Role of Labor Movement in Technological Change during the 1970s and the 1980s. In: Impagliazzo, J., Lundin, P., Wangler, B.: History of Nordic Computing 3: Third IFIP WG9.7 Conference, HiNC 3, Stockholm, Sweden, October 18-20, 2010: Revised Selected Papers. Springer, Heidelberg (2011) 
20. Magnusson, L.: Den tredje revolutionen - och den svenska arbetsmarknaden. Prisma, Stockholm (2000)

21. Johansson, A.L.: Teknikoptimismen i den svenska modellen. In: Beckman, S. (ed.): Teknokrati, arbete, makt. Carlsson, Stockholm (1990)

22. Tekniken och morgondagens samhälle. Tiden, Stockholm (1956)

23. LOs handlingsprogram för företagsdemokrati och data. Landsorganisationen i Sverige, Stockholm (1975)

24. Solidariskt medbestämmande: Rapport till LO-kongressen 1976: Med kongressens beslut. Prisma i samarbete med Landsorganisationen i Sverige, Stockholm (1976)

25. Rolandsson, B.: Facket, informationsteknologin och politiken: Strategier och perspektiv inom LO 1976-1996. Göteborgs universitet, Göteborg (2003)

26. Datorerna och arbetslivet: Rapport från TCOs arbetsgrupp för datafrågor. TCO, Stockholm (1978)

27. Datorerna och samhällsutvecklingen: Debattinlägg vid Tage Erlanders datasymposium 1980. Tiden, Stockholm (1980)

28. Johansson, I.: För folket och genom folket: Om idéer och utvecklingslinjer i studieförbundens verksamhet. Liber, Stockholm (1988)

29. Sejersted, F.: The Age of Social Democracy: Norway and Sweden in the Twentieth Century. Princeton University Press, Princeton (2011)

30. Emanuel, M. (ed.): Folkbildning kring datorn 1978-85: Transkript av ett vittnesseminarium vid Tekniska museet i Stockholm den 9 oktober 2008. KTH, Stockholm (2009)

31. Datoranvändning: Från samråd till medbestämmande. LO och Brevskolan, Stockholm (1978)

32. Datorer på människans villkor. ABF, Stockholm (1979)

33. Utbult, M.: Vi väljer vår framtid: Datorerna, makten och våra jobb. Brevskolan i samarbete med LO, Stockholm (1983)

34. Sköld, K., Anér, K., Nilsson, L., Wallander, G.: Styra eller styras? Människan och datorn. Sveriges kyrkliga studieförbund, Frikyrkliga studieförbundet, KFUK-KFUM:s studieförbund, Stockholm (1983)

35. Jansson, L., Pettersson, B.: Den elektroniska demokratin. Nykterhetsrörelsens bildningsverksamhet. Johanneshov (1984)

36. Henriksson, S.: De galna åren - en efterskrift. In: Atlestam, B. (ed.): Informationssamhället - åter till framtiden. Vinnova, Stockholm (2004)

37. Johansson, J.: Du sköna nya tid? Debatten om informationssamhället i riksdag och storting under 1990-talet. Tema, Linköping (2006)

38. Brynjolfsson, E., McAfee, A.: The Second Machine Age: Work, Progress, and Prosperity in a Time of Brilliant Technologies. W. W. Norton \& Company, New York (2014) 